\title{
Pre-service teachers' conceptual understanding of the standing wave concept
}

\author{
Iş1l Aykutlu
}

Hacettepe University, Faculty of Education, Department of Mathematics and Science Education, Department of Physics Education, 06800 Beytepe, Ankara, Turkey, aykutlu@ hacettepe.edu.tr

\section{Sevim Bezen}

Hacettepe University, Faculty of Education, Department of Mathematics and Science Education, Department of Physics Education, 06800 Beytepe, Ankara, Turkey, sevimbezen@ hacettepe.edu.tr

\section{Celal Bayrak}

Hacettepe University, Faculty of Education, Department of Mathematics and Science Education, Department of Physics Education, 06800 Beytepe, Ankara, Turkey, cbayrak@ hacettepe.edu.tr

\begin{abstract}
In this study, the aim is to determine pre-service teachers' conceptual understanding of the standing wave concept. Pre-service teachers' conceptual understanding of the standing wave concept was determined through the phenomenological pattern, and the aim was to lay bare how they made sense of this phenomenon, how they perceived and experienced it. The study was conducted with the participation of 13 pre-service teachers. One closed-end question was used to determine pre-service teachers' demographic characteristic, and five open-ended questions were used to determine their conceptual understanding of the standing wave concept. Data were obtained through semi-structured interviews conducted individually with the pre-service teachers. Because their answers varied, they were defined and analyzed through a new map with "Answer Sculptures." At the end of the study, it was determined that pre-service teachers have issues with their conceptual understanding of the standing wave concept; they have incomplete and non-scientific information. It was also seen that only a couple of pre-service teachers have a complete understanding of the standing wave concept.
\end{abstract}

Keywords: Conceptual understanding, Pre-service teachers, Science education, Standing wave

\section{Öğretmen adaylarının duran dalga kavramına yönelik kavramsal anlamaları}

ÖZ Araştırmada öğretmen adaylarının duran dalga kavramına yönelik kavramsal anlamalarının belirlenmesi amaçlanmıştır. Öğretmen adaylarının duran dalgaya yönelik kavramsal anlamaları fenomenoloji deseni aracılığıyla belirlenmiş ve onların bu fenomene yükledikleri anlamın ve o kavramı nasıl algıladıklarının, deneyimlediklerinin ortaya konması hedeflenmiştir. Araştırma 13 öğretmen adayı ile yürütülmüsstür. Araştırmada veri toplama aracı olarak öğretmen adaylarının demografik özelliklerinin belirlenmesi için bir kapalı uçlu sorudan ve duran dalgaya yönelik kavramsal anlamaların belirlenmesi için beş açık uçlu sorudan yararlanılmıştır. Veriler öğretmen adayları ile bireysel olarak gerçekleştirilen yarı yapılandırılmış görüşmelerle toplanmıştır. Araştırmada öğretmen adaylarından gelen yanıtlar farklılık gösterdiğinden, 'Answer Sculptures' modeli tercih edilerek yeni bir harita aracıllı̆̆ıla betimlenerek analiz edilmiştir. Araştırma sonucunda öğretmen adaylarının duran dalga kavramına yönelik kavramsal anlamalarında sorunlar olduğu, eksik bilgiye ve bilimsel olmayan görüşlere de sahip oldukları belirlenmiştir. Duran dalga kavramını sadece birkaç ögretmen adayının tam olarak anlamlandırdığı ortaya çıkmıştır.

Anahtar

Duran dalga, Fen eğitimi, Kavramsal anlama, Öğretmen adayları

Citation:

Aykutlu, I., Bezen, S., \& Bayrak, C., (2021). Pre-service teachers' conceptual understanding of the standing wave concept. Turkish Journal of Education, 10(1), 1-22. DOI: 10.19128/turje.744113 


\section{INTRODUCTION}

Physics of waves is one of the fundamental topics of physics. It also includes such topics of physics as acoustics, physical optics, quantum mechanics, and electromagnetic waves. In other words, this comprehensive field within physics contributes to a better understanding of physics as a field. However, such comprehensiveness is usually considered to be a disadvantage by the students because physics of waves, just as the concept of physics itself, is known to be seen as complicated and challenging by students, and students indicated to have experienced difficulties in this (Duit, 2009). It can be said that students think of the physics of waves as a complex topic, including abstract concepts and mathematics, and thus they have conceptual deficiencies and misconceptions (Maurines, 1992). In this respect, this study aims to examine standing waves, a topic under the physics of waves, and to determine pre-service teachers' conceptual understanding of the standing wave concept. Thus, the study aims to lay bare how pre-service students conceive of the standing wave and what their incomplete or incorrect knowledge is.

In theory; it is known that when a vertically vibrated string with one open and one fixed end is periodically vibrated in a certain mode, the wave will move sinusoidally. When this wave reaches the end of the string with a length of $\mathrm{L}$, reflection takes place and waves that move in the opposite direction on the string merge (Tipler \& Mosca, 2003). When the reflected wave reaches the fixed end, and when an appropriate relationship occurs between frequency (f), length of the string (L), a mass of the string per length unit $(\mu)$, and tensile force of the string $(T)$ standing wave occur on the string. Because a simple harmonic motion takes place on each point of the string, the string vibrates horizontally, and during this vibration, stagnancy is preserved on the nodal points of the wave pattern. In other words, the energy density of the standing wave varies according to frequency and amplitude (Serway \& Beichner, 1997). Standing wave, which can be defined as having peak and bottom points always observed in the same dimension, can be said to be a same-frequency wave stemming from the same source or two same-frequency waves stemming from the same source. At the same time, a standing wave is also defined as deadlock wave that can go neither the right nor the left, forward or backward (Halliday et al., 2013), because the standing wave is such wave whose energy remains at a specific place instead of going through the environment. This characteristic is found only in standing waves, and incident wave and reflected wave are superimposed to create the standing wave pattern. Because the wave is standing at the nodal points, where density is zero in the pattern, the total wave is called a standing wave (Young et al., 2004). In other words, there is zero motion in nodal points. Each particle of the environment is exposed to maximum motion from the balance state at antinode points; however, each particle with an opposing phase can go to a balanced state with a simple harmonic motion. As a result, motion for particles in all values of certain intervals is again zero (Serway \& Beichner, 1997). When the standing wave concept is examined in daily life, it can be said that a standing wave is observed in bows, water, sound, and electromagnetic waves. That is to say, specific examples from daily life can be given to standing wave concept. For instance, waves, which reach a harbor straightforwardly and perpendicularly, return without breaking, and this wave follows the incident wave. In perpendicular berths, a passing side boat would shake a perpendicularly standing boat in the harbor more. Here, too, the wave is reflected the same way as it does when it hits on a steep wall, and thus a boat on the shore rocks more (Young et al., 2004). In another example, when we push our finger on a string instrument and make sure that point becomes unmoving - in other words, a node point - the type and resonance frequency of the wave may change. As such, new notes occur, and compositions are made. In other words, the frequency of a string instrument may vary when the length of the string or its F tightening is altered (Serway \& Beichner, 1997). In wind instruments, certain holes are likewise made to enable free vibration of air. Thus, the resonance frequency can be continuously changed with the air inside, and the standing wave can be formed within the instruments (Tipler \& Mosca, 2003). Finally, when we put two loudspeakers across each other, the loudspeakers that propagate sound at the same frequency and density can be said to emit two identical waves in 
opposing directions and that a standing wave pattern can be obtained with the superposition of these two waves (Serway \& Beichner, 1997).

\section{Literature Review}

When literature concerning this study was examined, it was seen that in the survey conducted by Rutherford (2013) high school students were asked to make measurements on vertical and horizontal standing wave systems and students' approach to experimental data through theoretical guessing. At the end of the study, it was indicated that taking standing wave as visuals ensures students have an opinion on two harmonics. Brody, Villhauer, and Espiritu (2014) examined how the microwave, which is an electromagnetic wave, forms a standing wave pattern. In this study, standing waves that form between the microwave transmitter and the metal plate were determined, and obtained data were supported by the theoretical model by physics students. That a simple experiment has rich equipment and that microwave creates a standing wave was established by the students in an experimental environment. Ventura, Carvalho, and Dias (2017) examined standing wave in which energy is transmitted from one point to the other with no change of place in its matters. In the study, the teaching of the standing wave was realized with computer-aided education, and as a result of the study, it was determined that high school students could easily make sense of standing wave with the help of videos. Moreover, it was argued that videos ensure a low-cost and easy-to-use learning tool, and that video modeling should be used to support teaching physics. In their research, Crockett and Rueckner (2018) examined the formation of a standing wave pattern with sound waves. While the study was realized in a lab environment within the department of physics, it was proven that the formation of the standing wave in sound waves could be seen in experimental activities. Moreover, it was indicated that lab environments enable students to concretize theoretical and abstract knowledge and to learn them properly. Bhathal, Sharma, and Mendez (2010) conducted physics experiment applications for engineering students and analyzed their learnings. In these experiments, they specifically underlined that especially the standing wave is conceptually difficult; thus, visualization of this experiment is essential. At the end of the study, it was determined that students' learning the standing wave experiment in the lab through visualization helps them concretize abstract concepts, and their theoretical knowledge is thus supported. It was revealed that students could have meaningful learning as such, and this topic becomes more interesting for them. In his study, Davis (2007) conducted a visual experiment by bringing a guitar to the classroom. High school students were given a chance to observe the standing wave that was formed on the guitar string and to make sense of how different notes are created by differently determining boundary conditions. As a conclusion in the study, it was determined that students learned the concept by having fun with increased interest using visual sources that support theoretical knowledge. Zeng et al. (2014) conducted research focusing on the formation of the standing wave in sound waves. In this research, within the context of experimental pattern, experiment and control groups were formed out of students enrolled at the department of physics; the subject was presented to the experiment group through illustration, and the control group was taught through the visuals available in the conventional physics course book. At the end of the study, it was indicated that course books should include illustrations for the teaching of abstract concepts since the experiment group was able to make sense of the concepts. Finally, Radinschi et al. (2017) taught engineering students standing wave by using computer-aided simulations. Arguing that stranding waves have an important place in the field of engineering, researchers indicated that they preferred simulations for effective teaching. As a conclusion, they emphasized that teaching conducted through computer-aided simulations was effective and that simulations used in teaching a topic are effective tools.

When national literature was examined, it was seen that standing waves were mentioned within the exercises of studies focusing on mechanical waves. In various studies, it was seen that stable wave as an expression was used especially in relation to interference. For instance, with activities on interference, Yavuz Özdemir and Kocakülah (2017) examined high school students' conceptual changes concerning this concept. Conducted with a control and experiment group, this study determined that students in the experiment group were able to correctly explain this phenomenon by 
mentioning stable waves in interference after the activities carried out with the group. Yalçın (2008) also scrutinized water waves through collaborative learning. In that study, water waves appearing to stand still was taken as the target behavior; and activities were carried out during the teaching of interference for this target behavior. At the end of the study, it was indicated that there was an increase in high school students' success.

As a result, the literature shows that the standing wave concept is mostly used for engineering or physics students at the high school and university level. In teaching standing wave, experiments, activities, simulations have been used, and various applications have been realized in a lab environment. Studies on this topic aimed to concretize the standing wave concept and facilitate teaching. However, no study was found that would reveal pre-service physics teachers' conceptual understanding of standing wave concept. This article aims to complement literature in this regard by determining how pre-service physics teachers' conceptual understanding of standing wave concept is.

\section{The Aim of the Study}

The standing wave happens on a wire, a plate, a bar, air column, sound or electromagnetic waves; it can take place in most systems which have a vibration. In other words, standing wave is a concept that should be mentioned during the teaching of waves (Serway \& Beichner, 1997). However, when literature on waves was examined, there were limited number of studies on waves. In the limited number of studies on waves, it was emphasized that students had a difficult time learning it as it is an abstract concept. Keeping in mind the aim of this study, Tongchai et al.'s (2009) study on high school students and physics undergraduates is noteworthy. Tongchai et al. (2009) developed a conceptual understanding test for mechanical waves which had questions on conceptual understanding questions on standing waves. Then, Barniol and Zavala (2017) applied this to students taking the "Fluids, waves, and thermodynamics" class, and tried to determine the questions and concepts that students had difficulty with. At the end of this study, it was revealed that students had difficulty in conceptual understanding standing waves and that there is a need for further studies to analyze this difficulty in detail. The fact that there is a limited number of studies on standing waves and the lack of studies in the literature on the conceptual understanding of pre-service physics teachers who take the same classes paved the way for conducting of this study. In other words, it was believed that pre-service physics teachers' knowledge of the topic is important and that there is a need for determining their conceptual knowledge of standing waves. To this end, this study focuses on this gap on standing wave concept in the field of physics education, and it aims to determine pre-service teachers' conceptual understanding of standing wave because it is believed that pre-service teachers' conceptual understanding will reveal their mental structures so that better solutions can be found for their education by their conceptual structures, and it is also believed that permanent learning can thus take place. In light of all of these, it can be said that the main problem sentence of the study is "How is the pre-service physics teachers' conceptual understanding of standing wave concept?"

\section{METHODOLOGY}

\section{Research Pattern}

Phenomenology pattern was selected because, in the study, the focus is on pre-service physics teachers' conceptual understanding of standing wave concept. After all, the study aimed to lay bare how pre-service teachers make sense of a phenomenon, how they perceive and experience it (Brew, 2001). The meanings pre-service teachers put on their own experiences were tried to be understood through their explanations with phenomenology. In other words, this pattern enables a thorough exploration of phenomena that we are aware of but unable to fully comprehend (Creswell \& Poth, 2015). 


\section{Study Group}

Since pre-service teachers' conceptual understanding of standing wave concept was examined in the study, it was decided that the study be conducted with the participation of 13 pre-service teachers enrolled as juniors at the department of physics education of a state university. Creswell (2014) reiterated Dukes (1984) and Polkinhorne (1989) who suggest a study group consisting of 3-25 people. Pre-service teachers were decided by criterion sampling, which is one of the purposeful sampling methods because the researchers wanted to work with individuals who would be suitable for the aim of the study with the experience of the phenomenon and who could reflect this (Yıldırım \& Şimşek, 2018). Moreover, for content-wise rich contexts to occur and for a thorough examination of the topic, pre-service teachers were expected to meet certain criteria and have certain characteristics (Patton, 2014). In the study, the criterion was that pre-service teachers have taken the vibrations and waves course and that they have already conducted the standing wave experiment in the laboratory. The teaching of these classes were carried out in accordance with the content of the present teaching program. In this respect, the aim was to work with pre-service teachers who have sufficient knowledge of the topic and a certain conceptual understanding by certain criteria. Moreover, the study group was selected voluntarily, and pre-service teachers' present state of employment-related to their demographics was questioned with one close-ended question. After examining their demographic characteristics, it was determined that seven of the pre-service teachers worked as trainees at various education centers, three intermittently and three continuously tutored high school students at the time of research. Since pre-service teachers have different experiences, it is thought that there could come about different views concerning standing wave. Consequently, by creating a heterogeneous study group, pre-service teachers' conceptual understandings that would be revealed due to their differences of experience were also meant to be examined. In this study, pre-service teachers' have differences of experience due to their demographic characteristics and that they could make draw different relations. Moreover, it can be said that this study does not aim to generalize based on Van Manen's (1990, p.22) dictum "The only thing that can be generalized in phenomenology is that nothing can be generalized.

\section{Data Gathering Tool and the Application}

A close-ended question was used to determine pre-service teachers' demographic characteristics, and then five open-ended questions were used in the study to determine their conceptual understanding of standing wave concept. These questions were directed at pre-service teachers who have completed the vibration and waves class in the fall semester of their junior year and the lab applications of this class in the spring semester. Data in this study were gathered through semi-structured interviews realized individually with the pre-service teachers. In qualitative studies, interviews are called purposeful chat (Smith, Flowers, \& Larkin, 2009). In this respect, the aim was to reveal pre-service teachers' experience and perception in the interviews which were realized thoroughly with the help of interactive and additional questions. Pre-service teachers were asked about their current state of employment within the context of the close-ended question. At the same time, their basic knowledge of standing wave and how they relate this existing knowledge of theirs was also investigated with the open-ended questions. These open-ended questions were prepared by the researchers based on literature and related theoretical texts, and they are such questions that would reveal conceptual understanding. Data gathering tool was prepared by taking into consideration the views of two experts from physics and physics education departments. In the study, pre-service teachers were asked to explain the concept of standing wave and to make connections between concepts so that they could evaluate their conceptual understanding. Additionally, the application of the study took two months, and the interviews conducted with the pre-service teachers took 30-35 minutes each. Data were recorded with a voice recorder, and then the researchers transcribed the semi-structured interviews. Then, data were analyzed by the researchers. 


\section{Answer Sculptures}

Because answers given by pre-service teachers vary, data analysis can be presented to the readers by using various explanatory models. In this study, the "Answer Sculptures" model was preferred, and the aim was to describe the structure of pre-service teachers' answers through a new map. In this map, there can be more than one sub-concept, and connections between main concepts can be easily shown. With this map, similarities in pre-service teachers' answers were taken into consideration, and categories of the map were formed. These categories represent a designed form of pre-service teachers' different views (Balta, 2018). Moreover, it should be kept in mind that this analysis is different from the SOLO analysis model because the SOLO analysis model has five thought phases into which the received answers are inserted. However, analysis is not done this way with answer sculptures that we use in this study; the analysis of the study resembles, in essence, the phenomenographic analysis (Sharma et al., 2004). In the study, just like in phenomenographic studies, qualitative data were used to define how pre-service teachers perceive the standing wave concept and to define the similarities in their perception (Marton, 1981). However, different from phenomenological analysis, main concepts, relationships between concepts, and the similarities between answers were determined within the context of the questions asked in the study; and these were explained in detail on the map. At the same time, pre-service teachers' correct, partly correct, incorrect, and irrelevant answers could be shown through geometrical shapes with the answer sculptures. In short, answer sculptures enabled all answers by pre-service teachers to be seen clearly on a map. During the analysis, answers were classified according to their similarities, and for each category, the number of pre-service teachers who gave those answers was expressed within geometrical shapes. All answers and frequencies concerning these answers were given in answer sculptures, and findings of the study were presented in a comprehensible manner for the readers.

In addition to these, as the answers were got through semi-structured interviews, the main question could be divided into two or more branches, and hence a branched map was made possible. It is thought that especially geometrical shapes play an important role in the branched map because while pre-service teachers' answers could be presented to the reader via these geometrical shapes, conceptual confusion was gotten rid of by creating a map in which the rectangle represents the correct answer, the pentagon represents the partially correct answer, a circle represents the incorrect answer, and the trapezoid represents the irrelevant answer. In short, pre-service teachers' answers were expressed in symbols in this study so that the readers reflect on them and that pre-service teachers' conceptual understanding is laid bare.

Moreover, through answer sculptures, pre-service teachers who expressed the correct answer with incorrect explanations or those who gave an incorrect answer with correct explanations could be indicated clearly (Balta, 2018). In this respect, it is thought that one should be careful with categories and connections when forming answer sculptures because one of the disadvantages of this analysis is its inability to clearly and openly gather together different and complex answers. To prevent this, answer sculptures for each question were formed so that the answers for each question could be opened and dealt with by the researcher. Finally, answer sculptures designed by the researchers were re-examined by two experts who hold PhDs in the field. Categories, connections between categories, and the appropriateness of answers to their geometrical shapes were checked by the experts. The experts evaluated the expressions by giving one point to the ones they considered to be correct and zero points for the ones they considered to be incorrect. At the end of the evaluation, the concordance between experts was determined to be 0.90. Then, experts sat down together to talk about their disagreements and reached a consensus and made sure to have $100 \%$ concordance. The final version of the obtained data was presented in the findings section of the study.

Consequently, in this study, analysis in the phenomenology pattern was conducted with answer sculptures. It is believed that this analysis reflects the data of the study. It is also believed that a new perspective is provided to literature by using answer sculptures. Examining Balta's (2018) study, it was seen that pre-service physics teachers' existing knowledge of 'black-body radiation' can be 
determined by using answer sculptures. The study indicated that answer sculptures are an effective way of putting forth the classification of the participants' answers and their conceptual understanding. It also contended that alternative concepts individuals have could be clearly seen by answer sculptures. It further argued that it is a tool that facilitates the effective solution of the problem by laying bare the interaction between the concept and the phenomenon.

Taking all of these into consideration, the process of the study was summarized in Figure 1 in terms of pattern, participants, data collection, and analysis.

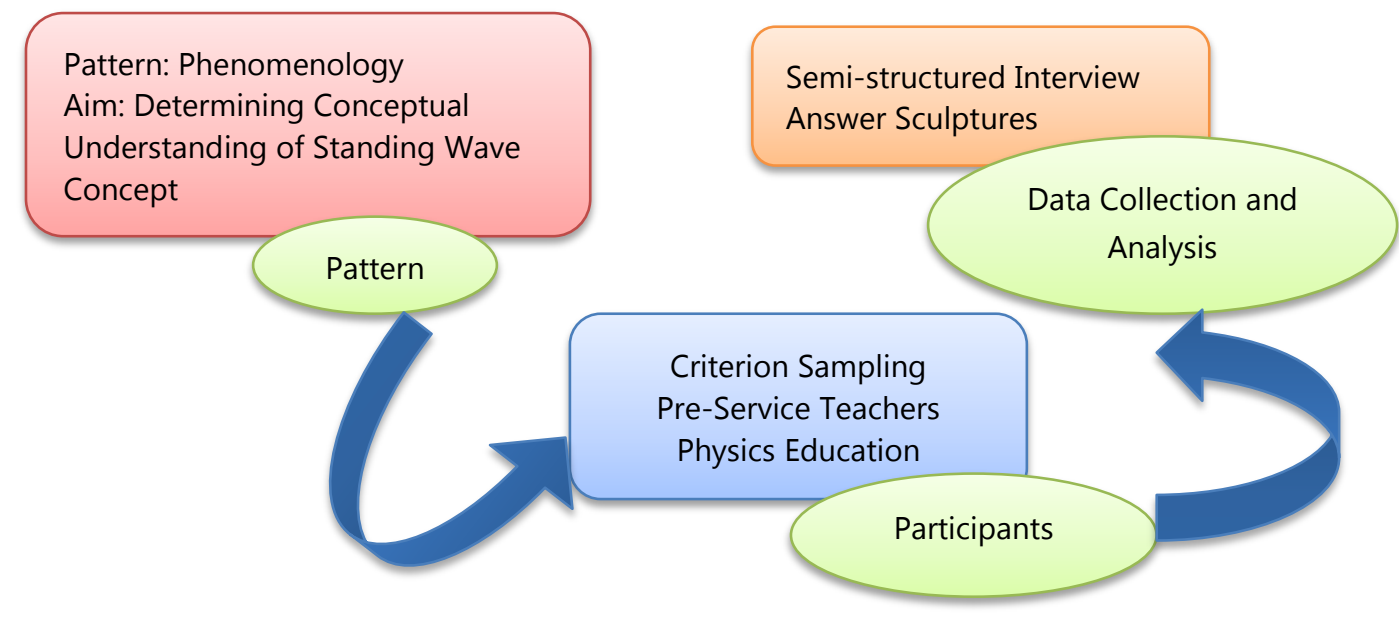

Figure 1. Research process

\section{Validity and Reliability}

Validity and reliability coefficients in qualitative studies were regarded to be dogmatic and thus were criticized in the deductive understanding of the positivist paradigm. Thus, believability and transferability are now preferred in qualitative studies (Corbin \& Strauss, 2008). In other words, a conceptual framework was built by surveying the literature in order to ensure internal consistency i.e. believability. Two experts were consulted for the questions which were formed based on this conceptual framework. The experts reached a consensus on the appropriateness of the questions and their sufficiency for the aim of the study. Then, pre-service teachers were asked questions and whether they had anything to add. Pre-service teachers were provided with a safe environment in which they could freely express their views, and it was underlined that their views would not be evaluated as part of their course grade.

For the external validity of the study - i.e. its transferability, the process of the preparation of the interview questions, the actual interviews themselves as well as their analysis process were explained in detail. Moreover, the study group, data gathering tool, data analysis and their interpretation were clearly defined so that the readers can easily understand them. In addition to these, data were examined by two experts to increase the consistency of the study, and the obtained results were comparatively examined. Consistency between the experts was calculated to be 0.90 by using Miles and Huberman's (1994) formula [Reliability= Number of Agreements/ Agreements + Disagreements]. Confirmability was ensured by explaining in detail everything that is done in the process and by storing the codes so that they could be examined later on as well (J. W. Creswell \& Creswell, 2018; Yıldırım \& Şimşek, 2018).

\section{Ethical Procedures}

Ethical principles and rules were followed during the planning of the research, data collection, analysis, and reporting. This research was found ethically appropriate with the decision numbered 35853172-600 at the meeting held by Hacettepe University Ethics Commission on 23 July 2019. 


\section{FINDINGS}

In this part of the study, pre-service teachers' conceptual understanding of standing wave concept was examined in terms of open-ended questions. Pre-service teachers' answers obtained from semistructured interviews were examined thoroughly under each question, and they were presented within answer sculptures.

\section{Q1. What does standing wave bring to your mind?}

This is the main question that brings out pre-service teachers' thoughts about standing wave. All preservice teachers that participated in the study answered this question. Answer sculptures in Figure 2 draw attention to the variety of the answers of pre-service teachers. It can be seen in the answer sculptures that there are twelve correct, five partially correct, five incorrect, and two irrelevant answers were given for this question. Moreover, by indicating in parentheses the number and frequency of pre-service teachers who have given that answer, pre-service teachers' views can be said to be put forth clearly. Lines on answer sculptures were used to relate answers given to the main question to each other and to relate the main question to concepts. In this respect, the most frequent expressions pre-service teachers used to explain standing wave is "it carries all characteristics of a wave" $(\mathrm{n}=11,85 \%)$, and "the motion takes place in two dimensions" $(\mathrm{n}=11,85 \%)$. When correct answers are examined, it is seen that pre-service teachers explained standing wave as having movement in one dimension $(\mathrm{n}=5,38 \%)$, carrying momentum and energy $(\mathrm{n}=5,38 \%)$, having propagation direction and speed $(\mathrm{n}=10,77 \%)$, moving in the $\mathrm{x}$-direction $(\mathrm{n}=11,85 \%)$, vibration taking place in the $y$-direction $(n=10,77 \%)$, the total displacement being zero in movement $(n=9,69 \%)$, and waves being superimposed $(n=8,62 \%)$. In conclusion, views were put together clearly and comprehensibly under categories taking into consideration the similarities in answers. When the partially correct answers of pre-service teachers are taken into consideration, it is seen that pre-service teachers thought they could observe standing wave only in mechanical waves $(n=10,77 \%)$ or electromagnetic waves $(n=3,23 \%)$, that they could not define exactly how energy transfer takes place $(\mathrm{n}=7,54 \%)$ nor they could explain it properly $(\mathrm{n}=2,15 \%)$, and that they described it as a non-standing wave although the name s standing wave $(n=3,23 \%)$. In terms of non-scientific answers, it was determined that pre-service teachers thought that there is no boundary requisite for the standing wave $(n=2,15 \%)$, that it could be observed in a system with one closed end $(n=2,15 \%)$, that it could be observed only in mechanical waves $(n=4,31 \%)$, and that movement happens in a single dimension $(\mathrm{n}=2,15 \%)$ (Figure 2). 


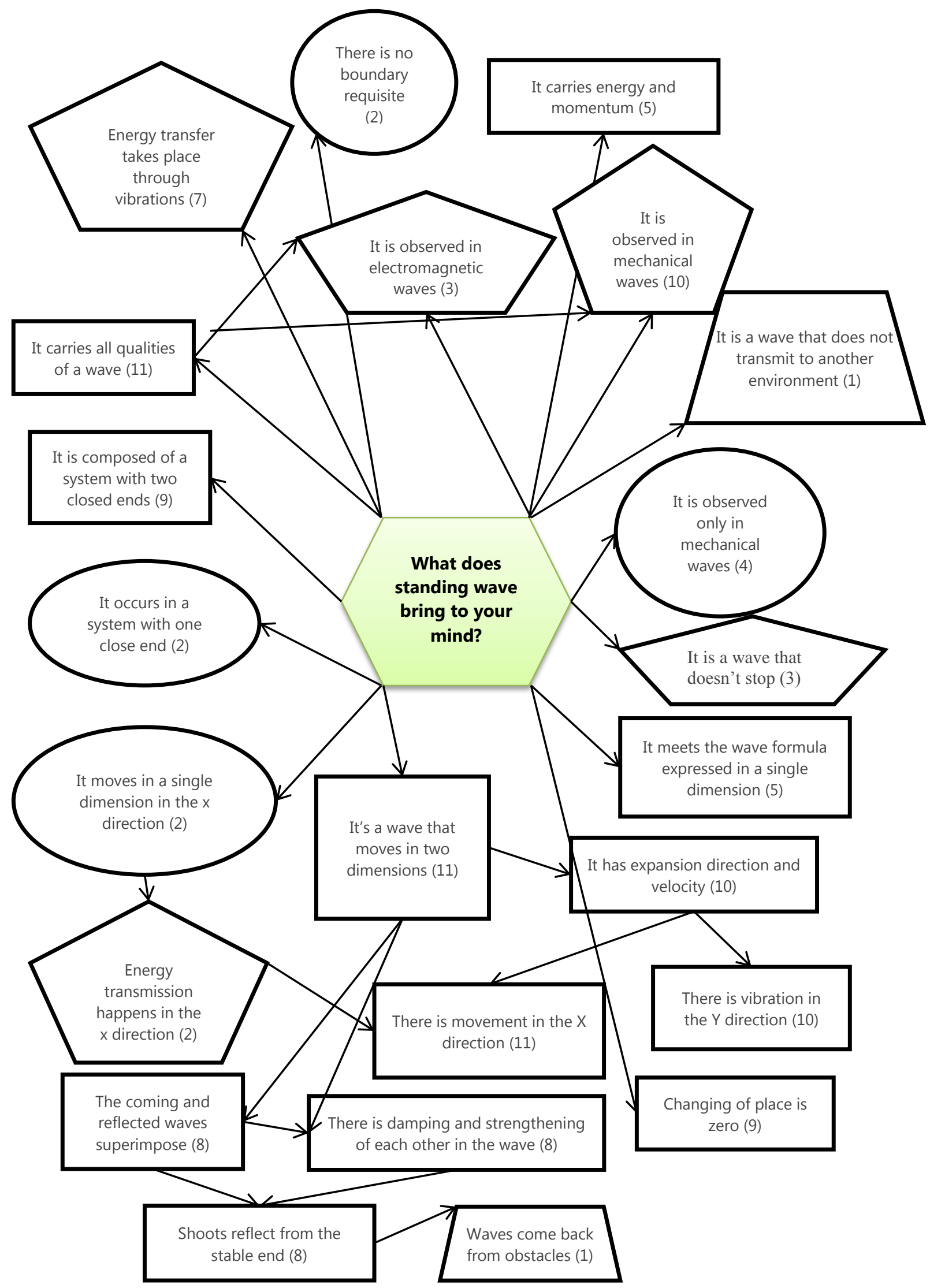

Figure 2. The answer sculpture of the first question (correct (rectangle), partially correct (pentagon), incorrect (circle), irrelevant answers (trapezoid)) 
Q2. While there are energy and momentum transmission in waves, how does this take place in standing wave?

In this question, while the energy and momentum transmission of standing wave wanted to be predicted, students were expected to know that standing wave carries the basic characteristics of waves (Figure 3).

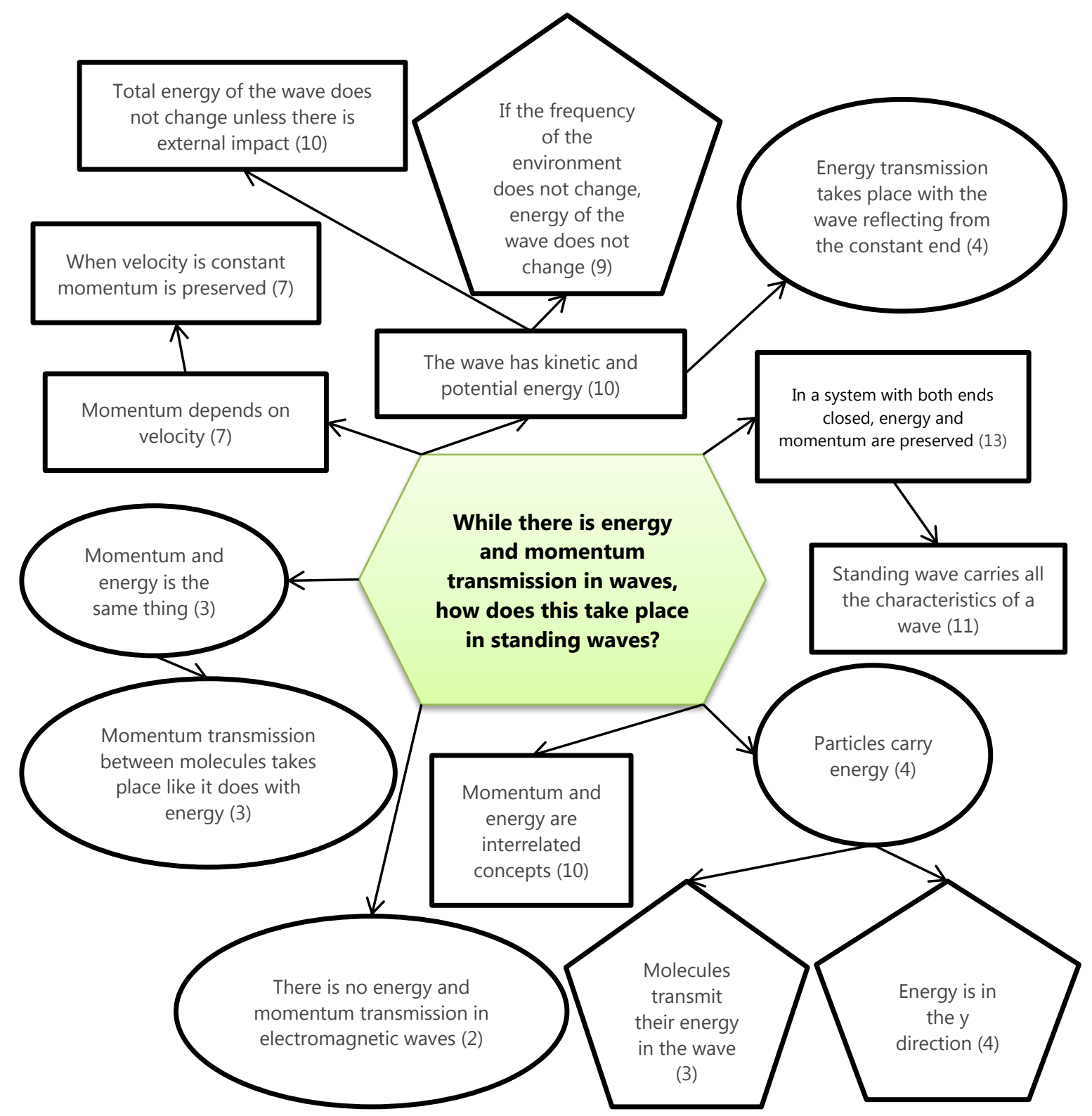

Figure 3. The Answer Sculpture of the second question (correct (rectangle), partially correct (pentagram), incorrect (circle), irrelevant answers (trapezoid))

In accord with the question, all of the pre-service teachers indicated that in a system with both ends closed, energy and momentum are preserved.

Pre-service teachers also indicated that the standing wave carries all of the characteristics of a wave $(\mathrm{n}=11,85 \%)$, it has kinetic and potential energy $(\mathrm{n}=10,77 \%)$, its energy would be preserved as long as there is no external impact $(\mathrm{n}=10,77 \%)$, momentum depends on velocity $(\mathrm{n}=7,54 \%)$, and momentum and energy are related concepts $(\mathrm{n}=10,77 \%)$. While pre-service teachers gave partially correct answers by indicating that energy depends on frequency $(n=9,69 \%)$, they were incorrect in assuming 
that energy transmission takes place by being reflected through the wall $(\mathrm{n}=4,31 \%)$, momentum and energy are the same things $(n=3,23 \%)$, particles carry the energy in the wave $(n=4,31 \%)$, or there is no energy or momentum transmission in an electromagnetic wave. It was also determined, just as in the previous question, those pre-service teachers could not fully express how energy transmission takes place $(n=3,23 \%)$ and that they thought there is energy only on the y-axis $(n=4,31 \%)$. Generally speaking, it was determined that pre-service teachers gave seven correct, three partially correct, and five incorrect answers. Lastly, it was noted that in this question, pre-service teachers gave incorrect explanations to their correct answers and partially correct explanations to their incorrect answers.

Q3. What do you think node and anti-node points in a standing wave mean?

This question aims to learn whether when talking about waves being superimposed; pre-service teachers know what the node and anti-node points on the standing wave are. When answer sculptures are examined, it can be seen that pre-service teachers usually used correct expressions in explaining the node and anti-node points and that they have comprehended these concepts (Figure 4).

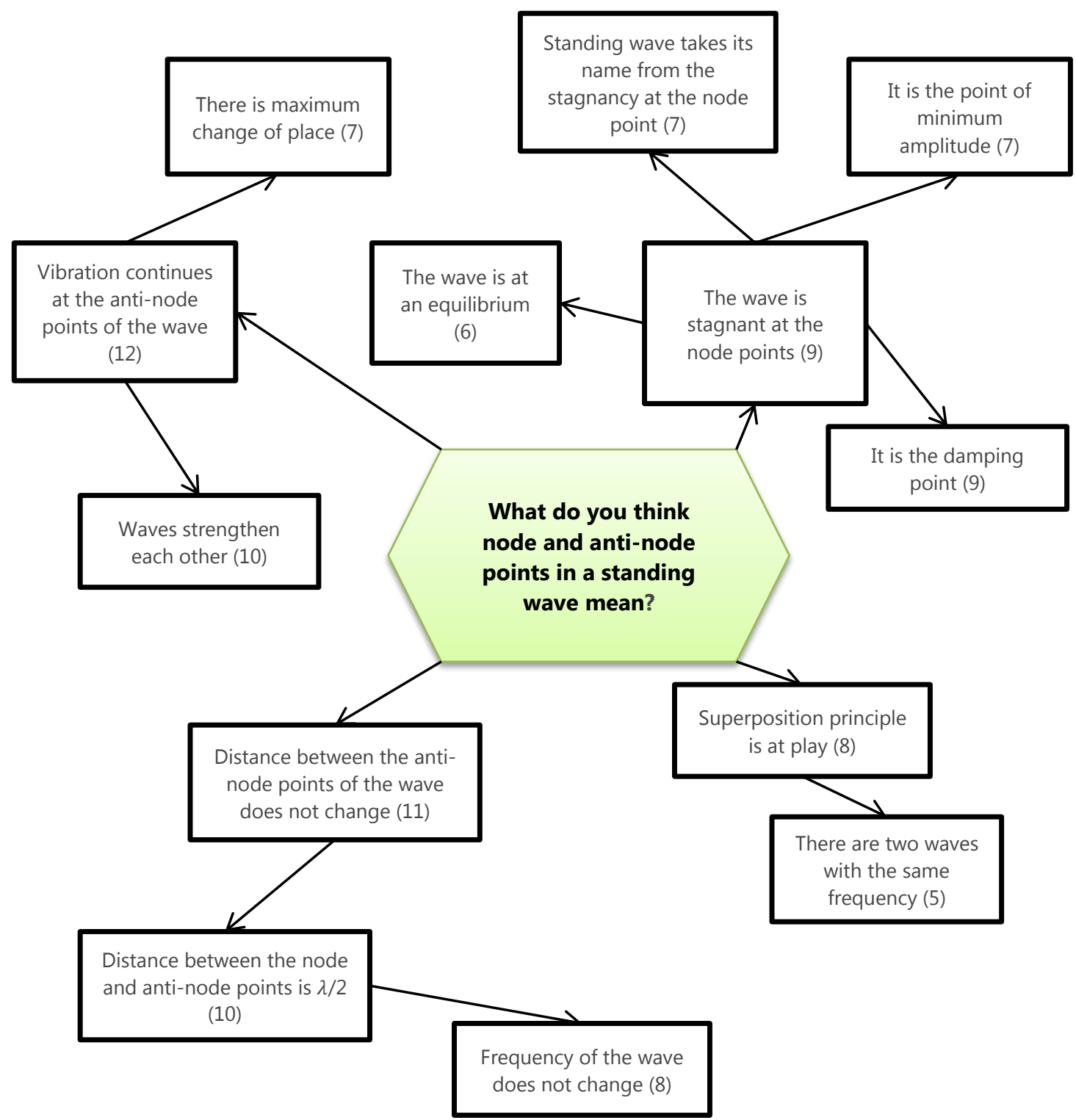

Figure 4. The answer sculpture of the third question (correct (rectangle), partially correct (pentagram), and incorrect (circle), irrelevant answers (trapezoid)) 
Pre-service teachers indicated that the standing wave is stagnant at the node points $(n=9,69 \%)$, that it takes its name from this characteristic $(n=7,54 \%)$, that the amplitude is minimum $(n=7,54 \%)$, that it is the damping point of the wave $(n=9,69 \%)$, and that the wave is at equilibrium at that point $(n=6$, $46 \%)$. They also emphasized that there is a maximum switch of place in anti-node points $(\mathrm{n}=7,54 \%)$, that waves strengthen one another $(n=10,77 \%)$, that vibration continues $(n=12,92 \%)$, and that the distance between node points do not change $(\mathrm{n}=11,85 \%)$. Additionally, they indicated that the distance between the node and anti-node points is $\lambda / 2(n=10,77 \%)$ and that this interval can change according to frequency $(n=8,62 \%)$. When talking about the superposition principle in waves, preservice teachers expressed that there are two waves with the same frequency $(n=5,38 \%)$.

As a positive finding, it should be said that pre-service teachers' correct answers and correct explanations could be easily presented due to answer sculptures. Their answers were presented to the reader clearly and openly.

Q4. Under what circumstances do you think the length of the standing wave changes?

In this question, pre-service teachers were asked to express the formulas they know conceptually and to determine the factors that could be effective in the change of wavelength by associating concepts with one another. In this respect, pre-service teachers mostly gave correct answers to the question; they indicated that the wavelength is directly proportional to the length of the string $(\mathrm{n}=11,85 \%)$, to the tension of the string $(n=10,77 \%)$, to velocity $(n=7,54 \%)$; they also indicated that it inversely proportional to the mass of the string $(\mathrm{n}=10,77 \%)$. It is thought that pre-service teachers gave correct explanations by taking their cue from the wave velocity equation (1) and with the direct proportion between velocity and wavelength equation (2).

$$
\begin{gathered}
\vec{v}=\sqrt{\frac{T \cdot L}{m}} \\
v=\lambda . f
\end{gathered}
$$

In the study, it was determined that pre-service teachers provided non-scientific explanations such as amplitude and width would change $(n=9,69 \%)$. Finally, in their correct answers, they indicated that the velocity of the wave depends on the temperature of the environment $(n=3,23 \%)$ and its density $(n=4,31 \%)$; thus they thought that the length of the wave might change depending on these. The preservice teachers $(n=3,23 \%)$ who talked about the pressure in the environment were evaluated in the partially correct answer category because they failed to mention statics (Figure 5). 


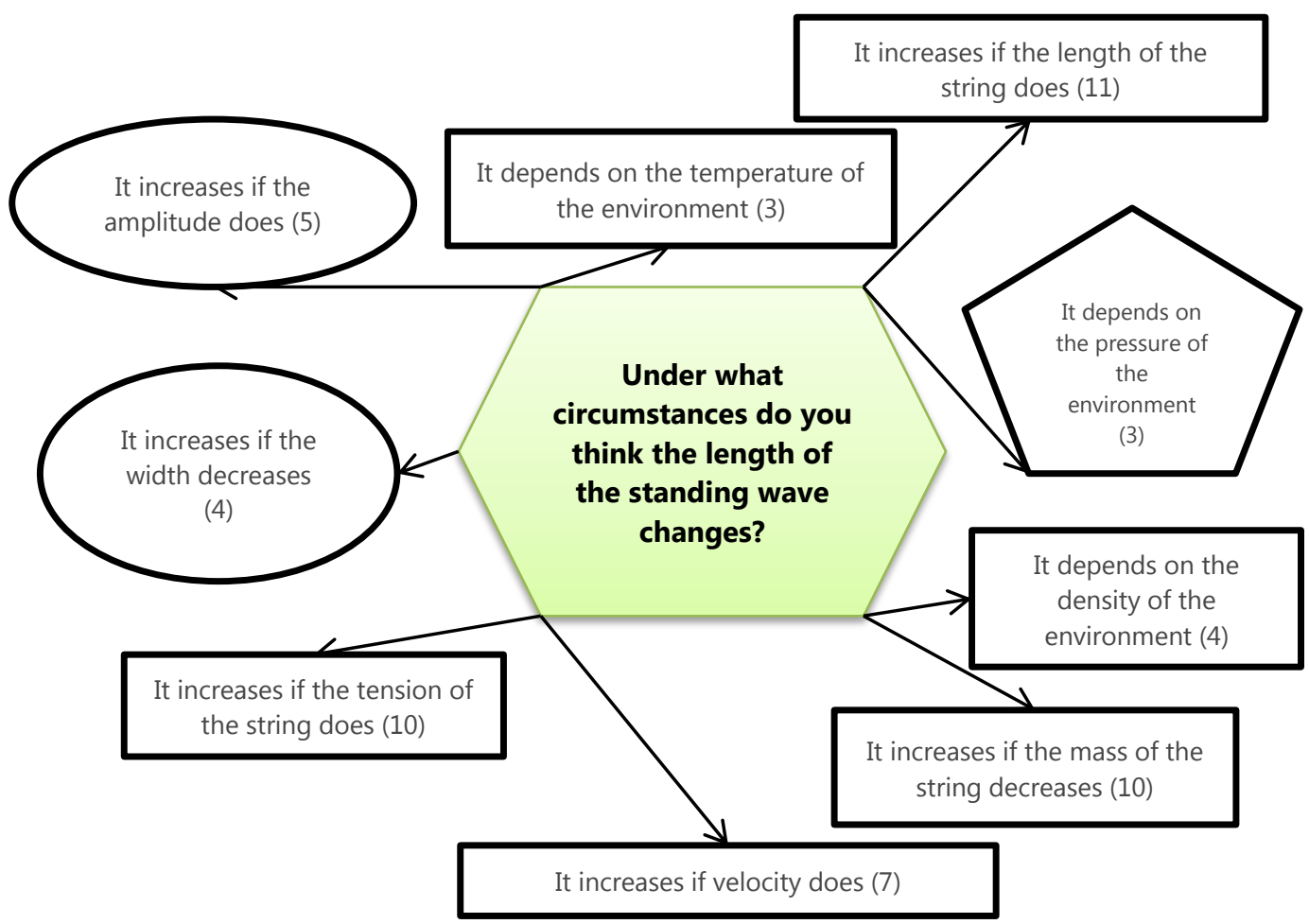

Figure 5. The answer sculpture for the fourth question (correct (rectangle), partially correct (pentagram), and incorrect (circle), irrelevant answers (trapezoid))

Q5. If you were asked to describe the movement of a standing wave, what kind of model would you use to do it?

In the last question, pre-service teachers were expected to answer the question by imagining an experimental environment or by associating their knowledge with daily life, because the last question goes beyond their level of knowledge and aims to put forth to what extent pre-service teachers can make sense of the subject. In this regard, it was noted that pre-service teachers could relate the standing wave the most with string instruments $(n=5,38 \%)$ and wind instruments $(n=5,38 \%)$ (Figure 6). Pre-service teachers could explain the question by drawing correct associations; they expressed the mechanism used in the standing wave experiment in the lab environment as a system that has a mass on one end and a vibrator on the other $(n=3,23 \%)$. Pre-service teachers who expressed the same example differently mentioned that they could create a standing wave pattern when they use the electric toothbrush as vibrators and when they hold it from the rear end by putting a thread on it $(n=2$, $15 \%)$. 


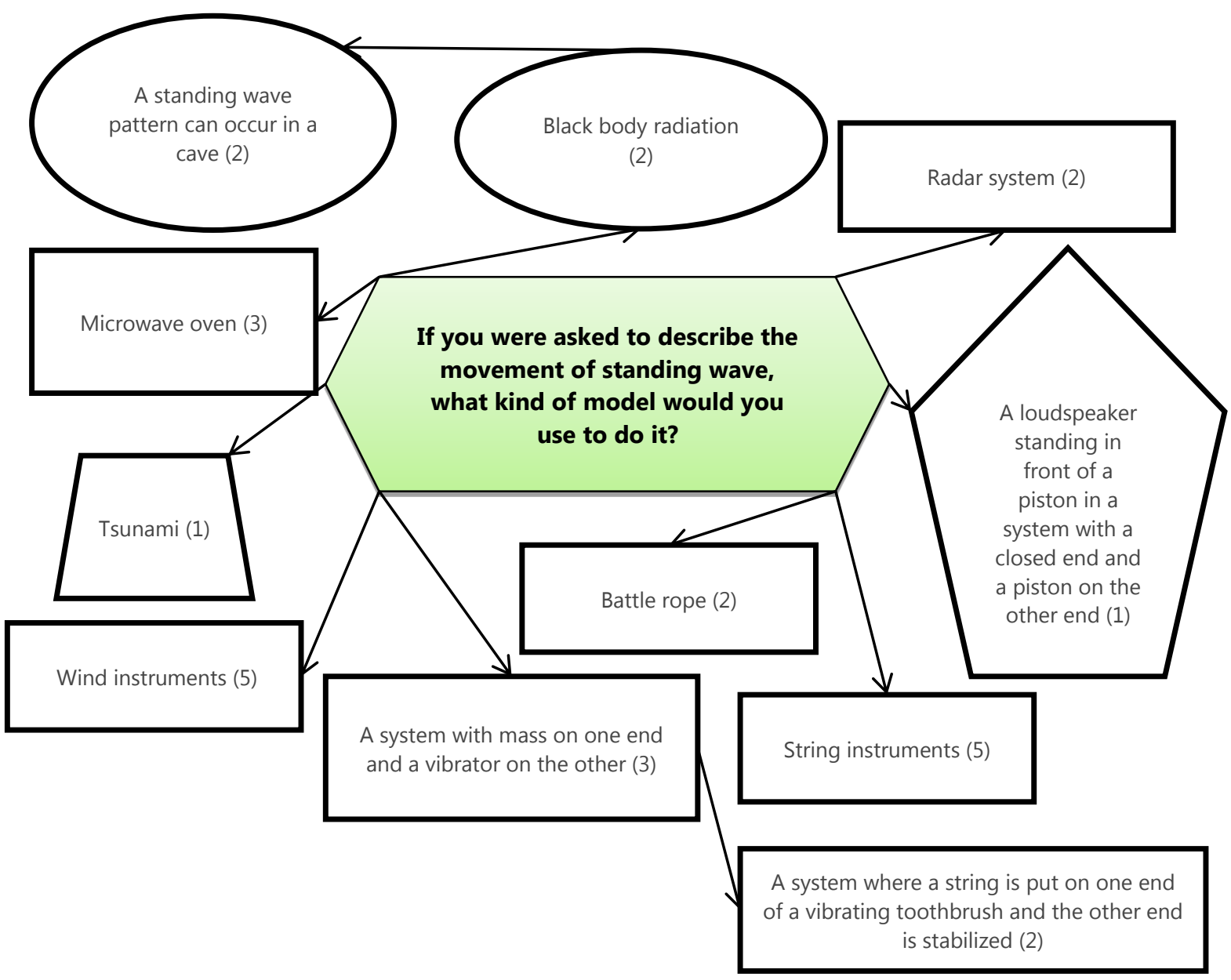

Figure 6. Answer sculptures of the fifth question (correct (rectangle), partially correct (pentagram), and incorrect (circle), irrelevant answers (trapezoid))

Likewise, those who thought of tools they use in daily life gave microwave ovens $(n=3,23 \%)$ and the radar system $(n=2,15 \%)$ as examples. Moreover, two pre-service teachers $(n=2,15 \%)$ could relate battle rope - fitness equipment they use in the sport salon - and the standing wave pattern. In addition to pre-service teachers who could give correct answers by reasoning through a system with a close end on both sides, there was also one pre-service teacher $(\mathrm{n}=1,8 \%)$ who gave an irrelevant answer by mentioning tsunamis. Another pre-service teacher tried to give an example of a system where sound waves could create a standing wave pattern, but it was determined that this pre-service teacher had incomplete points in their example $(\mathrm{n}=1,8 \%)$. One of the most different findings in the study is the presenting of black body radiation as a standing wave pattern $(n=2,15 \%)$. Pre-service teachers contended that they took black body radiation as rays reflected in a cave and that these rays could create a standing wave pattern by being superimposed.

\section{DISCUSSION}

Q1. What does standing wave bring to your mind?

In the study, pre-service teachers' different views on standing waves were put forth with the help of answer sculptures. The analysis of semi-structured interview questions through answer sculptures showed that pre-service teachers have incomplete or incorrect information about standing waves. For instance, pre-service teachers indicated that standing waves can only occur in mechanical waves and 
that they can be observed only in a system with a closed-end. At the same time, they expressed that a standing wave does not have any boundary requisite and that energy transmission and propagation direction would be on the x-axis. Thus, these pre-service teachers also argued that the movement takes place in a single dimension. In other words, research shows that pre-service teachers have not fully comprehended the concept of the standing wave. It was thought that this lack of scientific knowledge stems from scrutinizing an abstract concept because it was determined that pre-service teachers could quickly write down the equation for a wave in a single dimension. However, it was revealed that preservice teachers have difficulty conceptually expressing the standing wave.

Q2. While there are energy and momentum transmission in waves, how does this take place in standing wave?

Some of the pre-service teachers expressed that they are aware of standing waves carrying the characteristics of a wave and that when energy-momentum transmission takes place, these are preserved in the system. In addition to pre-service teachers who could draw correct associations, some pre-service teachers could not define energy transmission, and who claimed that energy is just dependent on frequency or that energy and momentum are the same things. Some pre-service teachers, just non-scientifically, expressed that energy transmission happened through particles, or that energy can only be in the y-axis, which is partially correct. At this point, it is thought that energy is considered to be an object by the pre-service teachers. It is believed that pre-service teachers should be made aware that the wave does not move like an object from one material environment to the other. Moreover, pre-service teachers, who thought that standing wave pattern could not be observed in electromagnetic waves, also argued that one could not talk about energy and momentum transmission in an electromagnetic wave. It is believed that the problem stems from pre-service teachers trying to explain an abstract concept in concrete terms because it was determined that pre-service teachers interpret concepts through mechanical reasoning and thus have misconceptions.

Q3. What do you think node and anti-node points in a standing wave mean?

From the findings of the study, it was seen that pre-service teachers explained the node and anti-node points with correct answers. In other words, pre-service teachers indicated that there is the minimum amplitude at the node point and that the wave is stagnant at this point. At the same time, they expressed that there is a maximum change of place and that the distance between the node and antinode points would remain the same as long as the frequency stays the same. On the other hand, preservice teachers argued that the superposition principle is at issue at the node and anti-node points; it is noted that they explained this while talking about the existence of two waves with the same frequency.

Q4. Under what circumstances do you think the length of the standing wave changes?

In the study, it was revealed that on the whole pre-service teachers know to what qualities the wavelength depends, but they think the wavelength might change with the change in amplitude and width. Since it is scientifically known that the wavelength does not change with the change in amplitude and width, it can be said that pre-service teachers have a conceptual misunderstanding.

Q5. If you were asked to describe the movement of a standing wave, what kind of model would you use to do it?

Pre-service teachers were asked in the study to relate standing wave as a concept to daily life and to model it. However, it was seen that pre-service teachers tried to express the standing wave through systems that represent it. It was also determined that pre-service teachers tried to explain their answers not only with correct explanations but also with non-scientific ones. Trying to associate the standing wave with black body radiation is one such example of non-scientific reasons. It is thought that preservice teachers ignored the particle characteristic of light at this point. Moreover, it is believed that pre-service teachers have incomplete knowledge of black body radiation. 


\section{CONCLUSION AND IMPLICATIONS}

Literature propounds that there have been numerous studies on mechanical waves (Linder, 1992; Maurines, 1992; Risch, 2010). Examining studies on conceptual understanding of mechanical waves, it has been seen that there are few studies on standing waves and that most of these studies focus on the learning difficulties of such concepts as wave velocity, wavelength, and the transmission of energy on the wave movement (Caleon \& Subramaniam, 2010; Halloun \& Hestenes, 1985; Kennedy \& De Bruyn, 2011; Maurines, 1992; Wittmann, 2002). In this study, too, the scope was not limited to mechanical waves; pre-service teachers' conceptual understanding of standing waves on wires, plates, sticks, air columns, sound and electromagnetic waves was examined. At the end of this study, it was determined that pre-service teachers have correct scientific knowledge along with incomplete or nonscientific knowledge on the subject. It was revealed that only a few of pre-service teachers could completely make sense of standing waves. In this respect, most of the pre-service teachers were determined to have difficulty in answering even the most basic questions on standing waves. As a result of the study, it was found out that pre-service teachers were unable to explain the energy transference, especially in a standing wave. Moreover, they had problems due to the wave as an object and due to being unable to relate the wave energy with amplitude. Pre-service teachers who held such misconceptions were seen to resemble black-body radiation to standing waves without making any distinction between the wave and particle characteristics of light. It was evident that even though preservice teachers who participated in this study had completed the learning of standing waves in the related theoretical and applied classes, they still have conceptual problems with standing waves. It is believed that this is because standing waves has been removed from the secondary school physics education program in Turkey and that students are taught about standing waves for the first time at the university level. In other words, pre-service teachers will not need any knowledge of standing waves while teaching high school students. In this respect, it is thought that pre-service teachers do not concern themselves with standing waves too much and do not analyze this concept in detail. It is believed that pre-service teachers are motivated only by getting a passing grade in relevant courses. Demir and Bütüner (2014) also argued that pre-service teachers are generally focused on passing a class rather than learning the content properly; therefore, they usually rely on memorization in their education process. However, it is predicted that there will be a need for an update of the teaching programs with the advancement of technology and that standing waves will be necessary to be reincluded in the program (Westbroek et al., 2005). Considering the recent history of secondary school physics education program, the program was updated in 2007, 2011, 2013, and 2018 in accordance with social needs and expectations (Dicle Erdamar, 2019). At this point, with another update in the program, which is already expected to take place, it will be difficult for pre-service teachers who have problems with a conceptual understanding of standing waves. To prevent this, pre-service teachers should be drawn attention to the concept during their undergraduate studies, and their inquiry-based learning process should be supported. In other words, the pre-service teacher should learn in a learning process where cognitive and critical thinking skills are effectively employed as opposed to rote learning of concepts (Zacharia, 2003). In this respect, it is believed that the teaching of standing waves should be done through experiment systems, simulations, activities, and augmented reality applications so that pre-service teachers can improve themselves and do not transfer incomplete information to their students (Ventura, Carvalho \& Dias, 2017). Moreover, pre-service teachers should be encouraged to do research by asking them to develop materials for standing waves in their project classes. For instance, it was seen in literature that Fang (2007) developed an experimental technique to observe the vibration of a standing wave. It was also seen that Lincoln (2020) employed LED for standing sound waves and developed Lincoln's Tube, which is an interesting method to demonstrate the characteristics of sound waves. Bozzo, Sabata, Pistori and Monti (2019) also developed a homemade experimental setup for standing waves; they showed the relationships between basic concepts related to standing waves such as wavelength, period, and thread tension. It was underlined that this setup increases students' interest and motivation. As can be seen in the studies in literature and as indicated by Lai and Hsu (2011), learning environments can thus be enriched, stronger learning can be ensured by including more senses into the teaching; and it is believed that this could positively contribute to pre-service teachers' conceptual understanding through a real learning experience. 
In terms of methodology, it was seen that that qualitative studies in physics education in Turkey prefer to present to the reader their findings, which were analyzed usually by descriptive or content analysis, via tables (Kaltakçı Gürel et al., 2017). However, it is believed that innovative strategies are needed to draw the readers' attention to the findings in these tables and to make it easier to make sense of them. To this end, in this study, as an innovative step, answer sculptures are were used to present pre-service teachers' answers in a holistic manner (Balta, 2018), because answer sculptures put all solutions together by using different geometrical shapes for correct, incorrect, partially correct, and irrelevant answers so that how pre-service teachers make sense of the topic and where their mistakes are can be easily seen. It is believed that answer sculptures, due to their nature, can be used in presenting in a different and holistic manner the findings obtained from qualitative research. Moreover, it is believed that answer sculptures facilitate researchers as well to understand conceptual understandings on various topics. In other words, it can be said that effective use of answer sculptures will bring a new breath to existing ways of presenting data.

\section{REFERENCES}

Balta, N. (2018). High school teachers' understanding of blackbody radiation. International Journal of Science and Mathematics Education, 16(1), 23-43. DOI: 10.1007/s10763-016-9769-z

Barniol, P., \& Zavala, G. (2017). The mechanical waves conceptual survey: An analysis of university students' performance, and recommendations for instruction. Eurasia Journal of Mathematics, Science and Technology Education, 13(3), 929-952. DOI: 10.12973/eurasia.2017.00651a

Bhathal, R., Sharma, M. D., \& Mendez, A. (2010). Educational analysis of a first year engineering physics experiment on standing waves: Based on the ACELL approach. European Journal of Physics, 31(1), 2335. DOI: $10.1088 / 0143-0807 / 31 / 1 / 003$

Bozzo, G., de Sabata, F., Pistori, S., \& Monti, F. (2019). Imaging and studying standing waves with a homemade melde-type apparatus and information and communication technology (ICT). The Physics Teacher, 57(9), 612-615. DOI: 10.1119/1.5135790

Brew, A. (2001). Conceptions of research: A phenomenographic study. Studies in Higher Education, 26(3), 271285. DOI: 10.1080/03075070120076255

Brody, J., Villhauer, E., \& Espiritu, H. (2014). Standing waves between a microwave transmitter and receiver. American Journal of Physics, 82(12), 1157-1160. DOI: 10.1119/1.4896355

Caleon, I. S., \& Subramaniam, R. (2010). Do students know what they know and what they don't know? Using a four-tier diagnostic test to assess the nature of students' alternative conceptions. Research in Science Education, 40(3), 313-337. DOI: 10.1007/s11165-009-9122-4

Corbin, J., \& Strauss, A. (2008). Basics of qualitative research: Techniques and procedures for developing grounded theory ( $3^{\text {rd }}$ edition). Sage Publications. DOI: $10.4135 / 9781452230153$

Creswell, J. W. (2014). Research design: Qualitative, quantitative, and mixed methods approaches (4 ${ }^{\text {th }}$ edition). Sage Publications. Retrieved from, http://fe.unj.ac.id/wp-content/uploads/2019/08/ResearchDesign_Qualitative-Quantitative-and-Mixed-Methods-Approaches.pdf

Creswell, J. W., \& Creswell, J. D. (2018). Research design: Qualitative, quantitative, and mixed methods approaches $\left(5^{\text {th }}\right.$ edition). Sage Publications.

Creswell, J. W., \& Poth, C. N. (2015). Qualitative inquiry \& Research design: Choosing among five approaches ( $4^{\text {th }}$ edition). Sage Publications. DOI: $10.13187 /$ rjs.2017.1.30

Crockett, A., \& Rueckner, W. (2018). Visualizing sound waves with schlieren optics. American Journal of Physics, 86(11), 870-876. DOI: 10.1119/1.5042245

Davis, M. (2007). Guitar strings as standing waves: A demonstration. Journal of Chemical Education, 84(8), 1287-1289. DOI: 10.1021/ed084p1287

Demir, S. B., \& Bütüner, K. (2014). Investigation of the opinions of pre-service social studies teachers regarding the field test. Mersin University Journal of the Faculty of Education, 10(2), 113-128. DOI: 10.17860/efd.79620

Dicle Erdamar, I. Y. (2019). Analysis of high school physics curriculum in the context of program development. Harran Education Journal, 4(2), 29-44. DOI: 10.22596/2019.0402.29.44

Duit, R. (2009). Students' and teachers' conceptions and science education. Retrieved from, http://archiv.ipn.unikiel.de/stcse/bibint.html

Fang, T. S. (2007). Analysis on non-resonance standing waves and vibration tracks of strings. European Journal of Physics, 28(4), 665-672. DOI: 10.1088/0143-0807/28/4/006 
Halliday, D., Resnick, R., \& Walker, J. (2013). Fundamentals of physics (10 ${ }^{\text {th }}$ ed.). Hoboken, NJ: Wiley.

Halloun, I. A., \& Hestenes, D. (1985). Common sense concepts about motion. American Journal of Physics, 53(11), 1056-1065. DOI: 10.1119/1.14031

Kaltakçı Gürel, D., Ölmeztürk, A., Durmaz, B., Abul, E., Özün, H., Irak, M., Subaşı, Ö., \& Baydar, Z. (2017). The content analysis of the graduate theses in physics education in Turkey between the years 1990 and 2016. Gazi Üniversitesi Eğitim Fakültesi Dergisi (GEFAD), 37(3), 1141-1172. DOI: 10.17152/gefad.335238

Kennedy, E. M., \& De Bruyn, J. R. (2011). Understanding of mechanical waves among second-year physics majors. Canadian Journal of Physics, 89(11), 1155-1161. DOI: 10.1139/p11-113

Lai, Y. S., \& Hsu, J. M. (2011). Development trend analysis of augmented reality system in educational applications. 2011 International conference on Electrical and Control Engineering, ICECE 2011 Proceedings, 6527-6531. DOI: 10.1109/ICECENG.2011.6056941

Linder, C. J. (1992). Understanding sound: So what is the problem? Physics Education, 27(5), 258-264. DOI: $10.1088 / 0031-9120 / 27 / 5 / 004$

Lincoln, J. (2020). The Lincoln's tube: A new apparatus for demonstrating sound standing waves. The Physics Teacher, 58(1), 74-75. DOI: 10.1119/1.5141985

Marton, F. (1981). Phenomenography - Describing conceptions of the world around us. Instructional Science, 10(2), 177-200. DOI: 10.1007/BF00132516

Maurines, L. (1992). Spontaneous reasoning on the propagation of visible mechanical signals. International Journal of Science Education, 14(3), 279-293. DOI: 10.1080/0950069920140305

Miles, M. B., \& Huberman, A. M. (1994). Qualitative data analysis: An expanded sourcebook. Sage Publications.

Patton, M. Q. (2014). Qualitative research \& Evaluation methods. Sage Publications.

Radinschi, I., Fratiman, V., Ciocan, V., \& Cazacu, M. M. (2017). Interactive computer simulations for standing waves. Computer Applications in Engineering Education, 25(3), 521-529. DOI: 10.1002/cae.21818

Risch, M. (2010). Investigations about science misconceptions. Ithaca, NY: Cornell University. Arxiv Preprint ArXiv10095524, September, 30. Retrieved from, http://arxiv.org/abs/1009.5524

Rutherford, C. (2013). A fresh look at longitudinal standing waves on a spring. The Physics Teacher, 51(1), 2224. DOI: $10.1119 / 1.4772032$

Serway, A. R., \& Beichner, J. R. (1997). Physics for scientists and engineers with modern physics. In Choice Reviews Online (Vol. 34, Issue 07). DOI: 10.5860/choice.34-3910

Sharma, M. D., Millar, R. M., Smith, A., \& Sefton, I. M. (2004). Students' understandings of gravity in an orbiting space-ship. Research in Science Education, 34(3), 267-289. DOI: 10.1023/B:RISE.0000044605.00448.bd

Smith, J. A., Flowers, P., \& Larkin, M. (2009). Interpretative phenomenological analysis: Theory, method, and research. Sage Publications. Retrieved from, https://uk.sagepub.com/en-gb/eur/interpretativephenomenological-analysis/book 227528

Tipler, P. A., \& Mosca, G. (2003). Physics for scientists and engineers. Retrieved from, https://www.pearson.com/uk/educators/higher-education-educators/program/Fishbane-Physics-forScientists-and-Engineers-Vol-I-Extended-Version-and-Physics-for-Science-and-Engineers-Vol-IIPackage-2nd-Edition/PGM1793879.html

Tongchai, A., Sharma, M. D., Johnston, I. D., Arayathanitkul, K., \& Soankwan, C. (2009). Developing, evaluating and demonstrating the use of a conceptual survey in mechanical waves. International Journal of Science Education, 31(18), 2437-2457. DOI: 10.1080/09500690802389605

Van Manen, M. (1990). Researching lived experience. New York: State University of New York. Retrieved from, https://www.sunypress.edu/pdf/52136.pdf

Ventura, D. R., de Carvalho, P. S., \& Dias, M. A. (2017). Standing waves in an elastic spring: A systematic study by video analysis. The Physics Teacher, 55(4), 232-234. DOI: 10.1119/1.4978723

Westbroek, H., Klaassen, K., Bulte, A., \& Pilot, A. (2005). Characteristics of meaningful chemistry education. In Research and the Quality of Science Education (pp. 67-76). DOI: 10.1007/1-4020-3673-6_6

Wittmann, M. C. (2002). The object coordination class applied to wave pulses: Analysing student reasoning in wave physics. International Journal of Science Education, 24(1), 97-118. DOI: $10.1080 / 09500690110066944$

Yalçın, Y. (2008). Effects of cooperative learning on students' achievement relating water waves. (Unpublished master's thesis). Graduate School of Educational Sciences, Dokuz Eylul University, İzmir.

Yavuz Özdemir, G., \& Kocakülah, M. S. (2017). Effects of application sequences of different instructional activities on students' conceptual changes about diffraction and interference. Amasya Education Journal, 6(2), 423-453. Retrieved from, https://dergipark.org.tr/tr/pub/amauefd/issue/33345/312240

Yıldırım, A., \& Şimşek, H. (2018). Sosyal Bilimlerde Nitel Araştırmalar [Qualitative Researches in Social Sciences]. Ankara: Seçkin Publication. 
Young, H. D., Freedman, R. A., \& Ford, A. L. (2004). Sears and Zemansky's university physics: with modern physics. Pearson Addison Wesley. Retrieved from, https://lib.ugent.be/en/catalog/rug01:001316743

Zacharia, Z. (2003). Beliefs, attitudes, and intentions of science teachers regarding the educational use of computer simulations and inquiry-based experiments in physics. Journal of Research in Science Teaching, 40(8), 792-823. DOI: 10.1002/tea.10112

Zeng, L., Smith, C., Poelzer, G. H., Rodriguez, J., Corpuz, E., \& Yanev, G. (2014). Illustrations and supporting texts for sound standing waves of air columns in pipes in introductory physics textbooks. Physical Review Special Topics - Physics Education Research, 10(2), 020110-1-020110-24. DOI: 10.1103/PhysRevSTPER.10.020110. 


\section{TÜRKÇE GENIŞLETILMIŞ ÖZET}

Dalgalar fiziği, fiziğin temel konuları arasında yer almaktadır. Aynı zamanda fiziğin akustik, fiziksel optik, kuantum mekaniği ve elektromanyetik dalgalar gibi konularını kapsamaktadır. Yani, fizik alanı içerisinde kapsamlı bir konu içeriğine sahip olan bu alan fiziğin anlaşılmasına destek olmaktadır. Ancak fiziğin bu derece kapsamlı olması öğrenciler açısından bir dezavantaj olarak ifade edilmektedir. Çünkü fizik kavramı gibi araştırmada da ele alınan dalgalar fiziğinin öğrenciler tarafından karmaşık ve zor olarak ifade edildiği ve bu konuda sıkıntılar yaşadıklarının belirtildiği bilinmektedir (Duit, 2009).

Öğrencilerin dalgalar fiziğini soyut kavramlar içeren ve matematiksel olarak zor olan bir konu olarak anımsadıkları ve bu nedenle kavramsal anlamalarında eksikliklerin ya da yanlış anlamalarının olduğu söylenebilir (Maurines, 1992). Bu bağlamda dalgalar fiziği içerisinde yer alan duran dalganın araştırmada irdelenmesi ve fizik öğretmen adaylarının duran dalgaya yönelik kavramsal anlamalarının belirlenmesi istenmiştir. Dolayısıyla araştırmada duran dalganın fizik öğretmen adayları tarafından kavramsal olarak nasıl anlaşıldığı, adayların eksik ve yanlış bilgilerinin ortaya konulması amaçlanmıştır.

Alanyazın incelendiğinde, duran dalga konusunun öğretiminin üniversite düzeyinde mühendislik ya da fizik bölümü öğrencileri ile daha çok ele alındığ 1 görülmüştür. Bu araştırmalarda duran dalganın öğretimine yönelik etkinlikler, deneyler, simülasyonlar kullanılmış ve laboratuvar ortamında çeşitli uygulamalar gerçekleştirilmiştir. Yani, araştırmalarda duran dalga kavramının somutlaştırılması ve öğreniminin kolaylaştırılması amaçlanmıştır (Bhathal et al., 2010; Brody et al., 2014; Crockett \& Rueckner, 2018; Davis, 2007; Radinschi et al., 2017; Rutherford, 2013; Ventura et al., 2017). Araştırmada da alanyazının tamamlayıcısı olarak duran dalga kavramına odaklanılmış ve ilerde bu kavramın öğretimi gerçekleştirecek olan fizik öğretmen adaylarının kavramsal anlamalarının belirlendiği bir araştırma makalesinin okuyuculara sunulması istenmiştir. Çünkü öğretmen adaylarının fizik konu bilgisinin önemli olduğu ve duran dalgaya yönelik kavramsal bilgilerinin belirlenmesinin ihtiyaç olduğu düşünülmektedir.

$\mathrm{Bu}$ bağlamda araştırmada fizik eğitiminde duran dalgalar konusundaki boşluk ele alınarak fizik eğitimine katkı sağlanması amacıyla öğretmen adaylarının duran dalga kavramına yönelik kavramsal anlamalarının belirlenmesi hedeflenmiştir. Böylece öğretmen adaylarının kavramsal anlamalarının zihinsel yapılarını ortaya koyacağına, kavramsal yapıları çerçevesinde öğrenimlerine yönelik daha rahat çözümler bulanabileceğine ve öğrenimin kalıcı olarak gerçekleştirilebileceğine inanılmaktadır. Tüm bu bilgiler 1şığında araştırmanın ana problem cümlesinin "Fizik öğretmen adaylarının duran dalga kavramına yönelik kavramsal anlamaları nasıldır?" olduğu söylenebilir.

Araştırmada öğretmen adaylarının duran dalgaya yönelik kavramsal anlamalarına odaklanıldığından fenomenoloji deseni tercih edilmiştir. Eğitim fakültesi fizik öğretmenliği bölümünde öğrenim gören 13 öğretmen adayı ile araştırma yürütülmüştür. Öğretmen adayları amaçlı örnekleme yöntemi içerisinde yer alan ölçüt örneklemeye uygun belirlenmiş̧ir (Yıldırım \& Şimşek, 2018). Araştırmada belirlenen ölçüte uygun olarak, konuyla ilgili yeteri kadar bilgisi ve belirli bir kavramsal yapıya sahip olan adaylarla çalışılmıştır. Ayrıca araştırmanın çalışma grubu gönüllülük ilkesine uygun seçilmiş ve bu öğretmen adaylarının çalışma durumları demografik özellikleri kapsamında kapalı uçlu bir soru ile sorgulanmıştır. Demografik özelliklerinin irdelenmesiyle; öğretmen adaylarının yedisinin araştırmanın gerçekleştiği süreçte çeşitli eğitim kurumlarında stajyer olarak çalıştığı, üçünün aralıklı ve üçünün de sürekli olarak lise öğrencilerine özel ders verdiği belirlenmiştir. Öğretmen adaylarının farklı deneyimlere sahip oldukları göz önüne alındığında, araştırmada duran dalga kavramına yönelik farklı düşüncelerin ortaya çıkabileceği düşünülmektedir. Sonuç olarak araştırmada heterojen bir çalışma grubunun oluşturulması ile aslında öğretmen adaylarının deneyim farklılıklarıyla ortaya çıkacak kavramsal anlamaların incelenmesi de istenmiştir. 
Araştırmada öğretmen adaylarının demografik özelliklerinin kapalı uçlu bir soruyla belirlenmesinin ardından duran dalgaya yönelik kavramsal anlamaların belirlenmesinde beş açı uçlu sorudan yararlanılmıştır. Araştırmada veriler öğretmen adayları ile bireysel olarak gerçekleştirilen yarı yapılandırılmış görüşmelerle toplanmıştır. Araştırma verilerinin 'Answer Sculptures' modeli tercih edilerek öğretmen adayı yanıtlarının yapısının yeni bir harita aracılığıyla betimlenmesi sağlanmıştır. Araştırmada fenomenografi araştırmalarında olduğu gibi öğretmen adaylarının duran dalga kavramını nasıl algıladıkları ve algılarındaki benzerlikleri tanımlamak için nitel verilerden yararlanılmıştır (Marton, 1981). Ancak fenomenolojik analizden farklı olarak, sorulan sorular çerçevesinde gelen yanıtlara yönelik ana kavramlar, kavramlar arası ilişkiler ve gelen yanıtlar arasındaki benzerlikler belirlenmiş ve bunlar detaylı olarak harita üzerinde açıklanmıştır. Aynı zamanda 'answer sculptures' aracılığıyla öğretmen adaylarının doğru, kısmen doğru, yanlış ve ilgisiz yanıtlarını geometrik şekiller aracılığıyla gösterilebilmiş ve öğretmen adayları tarafindan gelen tüm yanıtların bir harita üzerinde net bir şekilde görebilmesine firsat sağlamıştır. 'Answer sculptures' aracılığıyla yanlış açıklamalarla doğru yanıtı ifade eden ya da doğru açıklamalarla yanlış yanıtı veren ögretmen adayları da net bir şekilde belirtilebilmiştir (Balta, 2018). Sonuçta araştırmada yararlanılan fenomenoloji deseninde alanyazından farklı bir analiz gerçekleştirilmiştir.

Araştırma sonucunda fizik öğretmen adaylarının duran dalga kavramına yönelik eksik bilgiye sahip oldukları, kavramsal anlamalarında sorunlar olduğu ve bilimsel olmayan görüşlere sahip oldukları belirlenmiştir. Duran dalga kavramını sadece birkaç öğretmen adayının tam olarak anlamlandırdığı araştırma sonucunda ortaya çıkmıştır. Diğer öğretmen adaylarının duran dalga kavramına yönelik temel sorulara bile doğru yanıt vermekte zorlandıkları tespit edilmiştir. Araştırmaya katılan öğretmen adaylarının duran dalga kavramının öğrenimini ilgili teorik ve uygulamalı derslerde tamamlamalarına rağmen, duran dalga kavramına yönelik hala kavramsal olarak sorunlar yaşadıkları ortaya çıkmıştır. $\mathrm{Bu}$ durumun duran dalga kavramının Türkiye'deki ortaöğretim fizik öğretim programından kaldırılmasından ve bu kavramın öğretiminin ilk defa üniversitede gerçekleştirilmesinden kaynaklandığı düşünülmektedir. Çünkü bu durum üniversitede ilk defa duran dalga kavramının öğrenilmesinin yanı sıra, lise öğrencileri ile etkileşimleri olan adayların duran dalga kavramına yönelik bilgiye de ihtiyaç duymadıklarını akla getirmektedir. Dolayısıyla adayların duran dalga kavramı üzerine yeterince eğilmedikleri ve yeterli düzeyde bu kavramı irdelemedikleri düşünülmektedir. Ancak ilerleyen yıllarda gelişen teknoloji ile öğretim programlarının yeniden güncellenmesinin ihtiyaç haline geleceği ve günlük hayatla ilişkili olan duran dalga kavramının tekrar programda yer alması gerekliğinin ortaya çıkacağı ön görülmektedir (Westbroek et al., 2005). Bu noktada duran dalgaya yönelik kavramsal anlamada eksiklikleri olan öğretmen adaylarının ilgili kavramının öğretimini gerçekleştirmede zorlanacakları söylenebilir.

Öğretmen adaylarının öğrencilere eksik bilgiler aktarmaması ve kendilerini geliştirebilmeleri adına duran dalga kavramının ögretiminin duran dalga deney sistemlerine, simülasyonlara, etkinliklere ve arttırılmış gerçeklik uygulamalarına yer verilerek gerçekleştirilmesi gerektiğine inanılmaktadır (Ventura et al., 2017). Ayrıca öğretmen adaylarından proje dersleri kapsamında duran dalgaya yönelik materyaller geliştirmeleri istenerek onların gelişiminin desteklenmesi ve öğrenmeye, araştırma yapmaya teşvik edilmeleri gerektiği düşünülmektedir.

$\mathrm{Bu}$ şekilde öğrenme ortamlarının da zenginleştirilebileceğine, daha fazla duyunun öğretim içerisine dahil edilerek daha güçlü öğrenme sağlanabileceğine ve gerçek bir öğrenme deneyimi ile öğretmen adaylarının kavramsal anlamalarına olumlu yönde katkı sağlanabileceğine inanılmaktadır (Lai \& Hsu, 2011). Son olarak araştırmanın yöntemi irdelendiğinde ise, alanyazında Türkiye'de fizik eğitimi alanında gerçekleşen nitel araştırmalarda genellikle betimsel ve içerik analiz yoluyla çözümlenen bulguların tablolar aracılığıyla okuyucuya sunumunun tercih edildiği görülmüştür (Kaltakçı Gürel et al., 2017). Ancak okuyucuların tablolar içerisinde yer alan bulgulara dikkatini çekmek ve bulguları anlamlandırmalarını kolaylaştırmak amacıyla, günümüzde yenilikçi stratejilere ihtiyaç olduğu düşünülmektedir. $\mathrm{Bu}$ yüzden araştırmada bulguların okuyucuya daha anlamlı ve yenilikçi bir tarzda sunulması istenerek, yenilikçi bir adım atılmış ve öğretmen adaylarının yanıtları bütüncül bir şekilde 'answer sculptures' aracılığıyla sunulmuştur (Balta, 2018). Çünkü 'answer sculptures' aynı çizim 
üzerinde doğru, kısmen doğru, yanlış ve ilgisiz yanıtları farklı geometrik şekiller aracılığıyla bir araya toparlayarak öğretmen adaylarının konuyu nasıl anlamlandırdıklarını ve nerelerde eksikliklerin olduğunu kolaylıkla anlaşılabilir bir şekilde ortaya koymaktadır. Ayrıca araştırmada yararlanılan 'answer sculptures'ın farklı konulardaki kavramsal anlamaların sergilenmesinde de araştırmacılara yol gösterici olacağına inanılmaktadır. Yani, 'answer sculptures'ın etkin bir şekilde kullanılması ile bulguların sunumunun alışılmışın dışında alana farklı bir soluk katarak gerçekleştirilebileceği söylenebilir. 